\title{
The Turkification of Toponyms in the Ottoman Empire and the Republic of Turkey
}

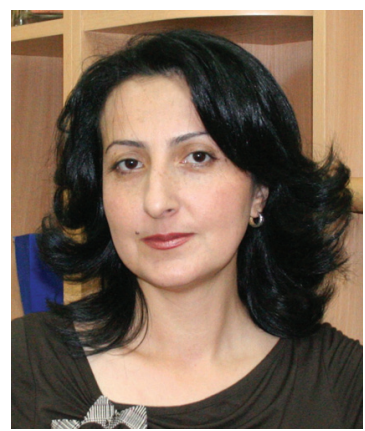

Lusine Sahakyan

Tn August 2009, during his visit to Bitlis, a formerly

Armenian city in the Eastern part of what is now Turkey, Turkish President Abdullah Gul said publicly that the original name of the present-day Gyouroymak province was "Norshin", which, he claimed, was in Kurdish. ${ }^{1}$ This statement should not be considered as a slip of the tongue; it represents traditional Turkish policies of Turkification and Kurdification of original Armenian toponyms. Norshin is purely an Armenian toponym both by its components "Nor"+ "shen", which mean a new settlement, and its pattern to form place names. All toponyms (villages, settlements, residential areas, etc.) with the component shen are indisputably Armenian as Martunashen, Vasakashen, Getashen, Vankshen, Hamshen, Verishen and the like.

It should be noted that, besides being linguistically stable phenomena, toponyms are valuable also as bearers of historical information. As such, they can have an effect on current ethnopolitical conflicts, if applied with the aim of distorting and manipulating the historical evidence. This truly strategic significance of the toponyms has not gone unnoticed: the ruling circles of the Ottoman Empire and those of its successor state, the Republic of Turkey, as once again confirmed by the recent reports in the BBC and the Turkish media, ${ }^{2}$ have devised and implemented consistent policies to falsify the origins and appropriate, through various ways and methods, the Armenian toponyms in the territory under their control.

The Turkish tribes who settled in various parts of Armenia in the $11-15^{\text {th }}$ centuries and later the Ottoman authorities were changing original Armenian place names in several ways. First, they were translating their meanings into Turkish such as Tantsout (place with a lot of pear-trees) into Armoudlou, Aghbyurashen (a village of springs) into Kyankendi, Karmrik (based on the word karmir, meaning "red" in Armenian) into Kezelja, Tsaghkadsor (a ravine of flowers) into Darachichek, etc.

Second, some Armenian toponyms, which had already been transformed somewhat from their original shape under the influence of local dialects, were converted to sound like a word with Turkic roots and pronunciation, thus utilizing the principle of contamination. Thus, Armtick (meaning roots in Armenian) was turned to Armoudi, Odzounkhach (a cross + snake) to Ouzounhach, Kyouropaghat (a title which goes back to Latin "curator palatii," which was given to especially Armenian governors by the Byzantine Emperors) to Gyurbaghdi, Karhatavan (settlement where stone in cut) to Karadivan, Jeghopourkents (place with o lot of walnut-trees) to Chopurgentz, ${ }^{3}$ etc.

Third, a widely spread method of distortion was to give new names to old settle- 
ments in an attempt to bury their ethnic affiliation in oblivion. ${ }^{4}$ Even Christian Armenian sanctuaries were given new names. Thus, the famous Armenian monastery Varagavank was renamed Yedikiliseh (meaning seven churches in Turkish), while the Holy Echmiadzin, the center of Armenian Church, where the Supreme Armenian Catholicos resided, was turned into Ouchkiliseh (three churches). According to our estimates, several dozens of settlements have been named by the word kiliseh or Gharakiliseh (black church) in both Western and Eastern Armenia.

Fourth, the attempts to give Turkish etymological explanations to the Armenian toponyms represented yet another method of Turkish appropriation campaign. Such faulty experiments were carried out, in particular, by Evliya Celebi, the Ottoman court historian of the $17^{\text {th }}$ century, whose interpretations have often served as basis for modern Turkish scholars. Here is an example. In his Book of Travels (Seyahatname), the old Armenian place name Bayberd or Baberd (which through dialectal and foreign lexical influences has undergone sound changes and consequently was pronounced as Baybourd) is etymologically explained as bay (meaning rich in Turkish) + yourd (settlement in Turkish). ${ }^{5}$ In fact, this name includes two ancient Armenian components Bay + berd, which respectively mean a den or an impregnable shelter and a stronghold or a fortress. As an ancient fortress, Baberd was mentioned by Movses Khorenatsi as early as in the $5^{\text {th }}$ century. ${ }^{6}$ Place names with the ending "berd" have been scattered throughout Armenia, as Tsamakaberd, Amberd, Vzhnaberd, Kharberd, Baghaberd, etc. ${ }^{7}$

Evliya Celebi went further to "reveal" that the original Armenian river name of Jorokh is a distorted form of the Turkish Joui-rouh, which according to him means "the river of the soul". ${ }^{8}$ In fact, the name Jorokh originates from the Armenian verb tsorel- tsorogh (flowing) in which the initial ts has been transformed to $j$ through sound interchange, a phenomenon peculiar to the Armenian language, as in tsanatsel $>$ janachel, and tskhni $>$ jkhni. ${ }^{9}$ Evliya Chelebi links to the Persians the name of the town Zarishat, ${ }^{10}$ which was actually built by the Armenian royal dynasty of the Orontids (570 BC - $200 \mathrm{BC})$. He derives the town name of $A k n$ from the name of a Byzantine princess Egin; ${ }^{11}$ however, Akn is a purely Armenian word meaning eye, spring or pit. ${ }^{12}$ In the place name of Pertek, which is a dialectal deformation of the original Berdak (a small fortress), Celebi tries to find the Mongolian equivalent for the word eagle. ${ }^{13}$

It is irrefutable that all the above-mentioned toponyms and others in Armenia have been recorded in historical sources far too earlier than any Turkic or Kurdish elements appeared on the Armenian Highland, which they gradually did only from the $11^{\text {th }}$ century onwards.

The "corrections" introduced by Celebi were by no means innocent etymological verbosities, but pursued the far-reaching goals of Ottomanizing the newly occupied territories. Evliya Chelebi was a state official, who also participated in Ottoman expansionist invasions. Thus, his etimological explanations had clear geopolitical motives.

Around the middle of the $19^{\text {th }}$ century Turkish authorities decided not only to dis- 
tort or change the names of Armenian provinces, regions and villages, but also to eliminate altogether the name Armenia. This policy was pursued especially after the Russo-Turkish war of 1877-1878, when the Armenian Question was included into the agenda of international diplomacy and European powers started exploiting it to derive various concessions from Turkey.

The government of Sultan Abdul Hamid II substituted the name Armenia with such terms as Kurdistan or Anatolia, fallaciously. Starting from 1880 the name Armenia was forbidden to be used in official documents. ${ }^{14}$ The Sublime Porte thus wanted to make everyone believe that the Armenian Question did not exist: if there was no Armenia, then there was no Armenian Question.

The historians are familiar with the plan of solving the Armenian Question with the assistance of England put forward by Kyamil Pasha, the pro-British Ottoman Grand Vizier and Commander-in-chief during the reign of Sultan Abdul Hamid II:

"If in Europe we have warmed a serpent (i.e. the Balkan peoples L.S.) in our bosom, we should not do the same in Asian Turkey. Common sense tells us to do away with all these elements that can pose the same threats to us in the future and become the cause and a tool of foreign interference. Now, today, at least Britain's interests demand that our territories in Asia Minor be safe from foreign meddling and all sources that may give others a pretext to meddle in our affairs. We, as well as the British not only do not recognize the word "Armenia", but we must smash to smithereens all jaws which dare to pronounce that word. To reach our sacred goal it is therefore imperative and the state law demands [from us] to make any suspicious elements unfit, sweep forever from the face of the earth this Armenian nation, to annihilate them recklessly and for good" (the emphasis is mine - L.S.). ${ }^{15}$

By deliberately distorting them, the Ottoman authorities were ascribing Armenian and Greek place names to a Turkish or Kurdish origin. At that stage, the Kurdish ethnic factor was used by the Ottoman rulers, for the Kurds were not yet viewed as a threat to the Ottoman Empire. Taking advantage of their religious fanaticism, in the 1890s Sultan Abdul Hamid, who was also known as "the father of the Kurds" (Bavê Kurda), ${ }^{16}$ organized the Armenian massacres through the Hamidiye regiments formed by Kurdish brigands and the regular Turkish army soldiers.

During Abdul Hamid's reign all Turkish and Kurdish resettlements were given new names, which were the names of nomadic tribes or various Ottoman sultans such as Hamidiye, Reshidiye, Aziziye, Mahmoudiye, etc. This policy became especially manifested during the reign of the Young Turks in 1908-1918.

The government of Young Turks also attached great importance to the changing of "non-Muslim" place names. They replaced many toponyms, some named after the Ottoman Sultans, with their own names such as Enveriye, Shevketiye, Mahmoutshevket-Pasha and the like. ${ }^{17}$ The "Resolution About the Resettlement of 
Refugees" ("Iskân-I Muhacirin Nizamnamesi"), a document adopted on May 13, 1913, ${ }^{18}$ served the specific Young Turk policy of total Turkification. The next step was made by Enver Pasha, the Young Turks' Minister of War, on January 5, 1916. ${ }^{19}$

Enver Pasha's decree sent to the Turkish military-political authorities demanded that all place names of Armenian, Greek, Bulgarian and other non-Muslim origins in the Ottoman Empire be transformed into Turkish ones. ${ }^{20}$ Below is the translation of his Decree (Emirname):

\section{DECREE}

1. It is important to change into Turkish all names of provinces, regions, villages, mountains and rivers belonging to Armenian, Greek, Bulgarian and other non-Muslim peoples. Making use swiftly of this favorable moment, we beseech your help in carrying out this order.

2. Cooperating with military commanders and administrative personnel within the boundaries of your jurisdiction, respective lists of name changes should be formed of provinces, regions, villages, etc. and be forwarded to military headquarters as soon as possible. After being studied and approved, these lists of proposed changes should be sent to the Ministry of the Interior and the Communications Ministry for generalization and implementation.

3. It is imperative that the new names reflect the history of our hardworking, exemplary and praise-worthy military. The glorified events of our present and past war experiences should, by all means, be mentioned. In case this is not possible, names of those who had highly moral principles and who have fallen rendering invaluable services to their country should be remembered; or names should be found that are appropriate to the given area's specific crop, product, trade or geographical situation.

Last but not least, teachers at schools in different parts of our Fatherland should find appropriate topics to teach about the given territory's glorious history, climate, crop, trade and culture. It should be borne in mind that any sudden change of a conventional name into an inconvenient or improper one may bring about the continuation of using the old name by the population. Therefore, new names should be chosen taking all this into consideration. In case such principles cannot be observed, then Ereghli, for exam-ple, should be turned into Erikli or Erakli, Gallipoli into Veliboli in order to maintain the roots of old names. 
Inspired by Enver's decree, the prominent military officer Huseyin Avni (Alparslan) Bey, the author of several articles about the Turkish language and culture, wrote: "If we want to be the owner of our country, then we should turn even the name of the smallest village into Turkish and not leave its Armenian, Greek or Arabic variants. Only in this way can we paint our country with its colors." ${ }^{21}$

As we see, he even goes a step further than his minister by suggesting that Arabic place names also undergo changes. Enver Pasha's decree mentioned only "Armenian, Greek, Bulgarian and other non-Muslim peoples". This testifies to the fact that during the Ottoman period, when the Sultan was considered the spiritual head (Caliph) of all Muslims, the Arabic and Kurdish toponyms were not yet regarded as threatening to the authorities. However, it should be remembered that the overwhelming majority of the names of places where the Kurds moved in Western Armenia were Armenian in origin with, at times, some aspects of local dialectal or foreign linguistic influences. After the Armenian Genocide, these toponyms have been attributed to Kurds.

During the war, the Armenian, Greek, Bulgarian and Aramaic toponyms were the first to be turned into Turkish..$^{22}$ A few examples will suffice to illustrate this process: in Bursa, the Antranos caza was turned into Orhanelli, Mikhalich was renamed Karajabey, the village Dimitri into Touran, the Rum village in Chorum into Yeni (new) Chamlejay; in Hamshen, the Armenian toponyms of Yeghnahovit (Elevit) was turned into Yaylakyolu, Vardanots into Gyullyu, Hamshen-i Sufla into Srakoy, Metsahor into Kaptanpasha, ${ }^{23}$ etc.; in Baberd, Aryutska (from the Armenian aryutslion) was renamed Gyokpnar, Ashotka into Gyuvenjirdere, Balahor into Akshar, Tandzut into Bughdayli, Ishkhandzor into Devtash. ${ }^{24}$ Numerous examples could be added to this list. But a few months later, on June 15, 1916 the Ottoman Military Headquarters disapproved of these changes, arguing that on the new maps these new names were causing confusion in military correspondence. ${ }^{25}$

Having been deprived of its original population, Western Armenia continues to lose, along with many other historical and cultural values, its centuries-old Armenian place names. They are being declared as Kurdish or Turkish. Haroun Tuncel, a Turkish historian, has admitted that "One cannot find in Turkey a scientific work that would deal with the origins of ancient toponyms for the simple reason that the person undertaking such an arduous task should be knowledgeable of the local dialects of several languages, including Persian, Arabic, Armenian, Zaza, Kourmanji, AssyrianAramaic, Sumerian and Akkadian... for any name considered Kurdish may well be either Sumerian, Akkadian or Turkish and any name considered Turkish may be either Arabic, Armenian or Akkadian in its origin". ${ }^{26}$

In an article, titled "28,000 toponyms were changed. Nobody knows which one comes from which language", ${ }^{27}$ Ş. Türker has included among Kurdish names such indisputably Armenian toponyms as Van, Antep (Aintap), ${ }^{28}$ Kharpet (Kharberd), Erzingan (Erzinjan<Erznka), Chermig (Jermuk), Kaghzman (Kaghzvan), Dersim, Tekor, Gerchanis (Kerchanitz, Kirchanitz), Palin (Balu), Jolemerk (Joulamerk), Gogsin (Koksi), Kers (Kars), Poulour (Blour), Pertak (Bertak), Gheghi (Keghi), Chermen (Jerme), Qop (Kop), Chemishgezek (Chemeshkatsag), Terjan (Derjan), 
Kemah (Kamakh), Ispir (Sper), Zaroushat (Zarishat), Artemetan (Artamed), Erdish (Arjesh), Zedkan (Zatkan), Tatos, Egin (Akn), Toukh, Keban (Kapan), Siverek (Sev Averak), Jirmik (Jermik), Sert (Sghert), Erkhvan-Argouvan (Argavan), and even Erzeroum (Erzroum< Erzen-el-Rum $<$ Artsen-el roum), Kilis (which is a distorted version of the word "Yekeghetsi", meaning Church), etc. ${ }^{29}$ It remains a mystery why and how the Muslim Kurds came to name their settlements Church (Kilis)?

The process of "nationalization" of toponyms was continued by the Kemalists, who were the ideological successors of the Young Turks. It gained momentum during the Republican period. Starting from 1923 the entire territory of Western Armenia was officially renamed "Eastern Anatolia". ${ }^{30}$ After the Kurdish rebellions in 1925, 1927 and 1936 in eastern part of the Republic of Turkey, the Turkish authorities started renaming the Kurdish and Zaza settlements as well. As early as 1935, the Interior Minister Shukru Kayan put forward a draft resolution to rename Dersim into Tunceli. It is worth noticing that in February 2009 Sharafettin Halis, a deputy in the Turkish Parliament from the Democratic Society Party (DTP), proposed that Tunceli be granted its former name of Dersim; he argued that people cannot forget this name as it has become sacred for them and was used both in their daily lives and in their songs, tales and novels. The proposal was, however, labeled a "manifestation of separatism" by the Turkish Minister of Justice. ${ }^{31}$

In 1940, the Turkish government issued a circular letter (No. 8589) which called for changing into Turkish all toponyms in foreign languages or with foreign roots, but the outbreak of World War II temporarily impeded its implementation.

A special article devoted to the changes of toponyms was included in the 1949 Provincial administrative law (II Idaresi Kanunu). Furthermore, a "Specialized Organization for Renaming Toponyms" (“Ad Değiştirme İhtisas Kurulu”) was initiated in 1957. This organization renamed 653 settlements in Erzurum, 169 in Adana, 366 in Erzinjan (Yerznka), 224 in Adyaman, 70 in Moughla, 88 in Afion, 70 in Eskishehir, 297 in Moush, 374 in Aghre (Ararat), 279 in Gaziantep (Aintap), 24 in Nevshehir, 99 in Amasia, 167 in Giresoun (Kirasoun), 647 in Nighdeh, 193 in Ankara, 343 in Gyumushkhaneh, 134 in Ordou, 168 in Antalya, 128 in Hakkari, 105 in Rize, 101 in Ardvin, 117 in Hatay (Alexandretta/Iskenderun), 117 in Sakaria, 69 in Ayden, 185 in Sparta, 110 in Balekesir, 112 in Ichel, 392 in Siirt (Sghert), 32 in Bilejik, 21 in Istanbul, 59 in Sinop, 247 in Bingyol (Byurakn), 68 in Izmir (Smyrna), 406 in Sivas (Sebastia), 236 in Bitlis, 398 in Kars, 19 in Tekirdagh, 182 in Bolou, 295 in Kastamonu, 245 in Tokat (Eudokia), 49 in Bourdour, 86 in Kayseri (Cesaria), 390 in Trebizond, 136 in Boursa, 35 in Krklareli, 273 in Dersim, 53 in Chanakkaleh, 39 in Kershehir, 389 in Shanli Ourfa (Ourha), 76 in Chankere, 26 in Kojayeli, 47 in Oushal, 555 in Chorum, 217 in Malatia, 156 in Zongouldak, 20 in Edirne, 647 in Mardin, 555 in Diarbekir, 83 in Manisa, 383 in Elazegh (Kharberd), and 105 in Kahraman Marash. ${ }^{32}$

After research work on 75.000 toponyms, the "Specialized Organization" changed 28.000 names, among which 12.000 were village names. According to H. Tunçel's estimates, 12.211 villages were renamed during the period of 1940-2000, which constitutes approximately 35 per cent of the villages..$^{33}$ 
The Turkish historian Ayse Hyur writes that during the reign of the Democratic Party ugly, humiliating, insulting or derisive names, even if they were Turkish, were subjected to changes. Village names with lexical components meaning red (kizil), bell (çan), church (kilise) were all changed. To do away with "separatist notions", the Arabic, Persian, Armenian, Kurdish, Georgian, Tatar, Circassian, and Laz village names were also changed. ${ }^{34}$ From 1981 to 1983 , the names of settlements on the Eastern and Western parts of the Black Sea also underwent changes.

Bilir, the author of "Let Tunceli Be Named Dersim", in an article published in the August 19, 2009 issue of "Bir Gun" daily, writes that, besides giving new names to the settlements, the Turkish authorities altered also the phonetic pronunciations of those old names to make them sound like Turkish words, as, for instance, Chinchiva to Shenyouva. This method of changing a toponym, as has already been mentioned previously, was suggested by Enver Pasha as early as 1916: “...change Ereghli into Erikli or Erakli, Gallipoli into Velipolou in order to maintain the old name roots" ${ }^{35}$. This phenomenon, however, has deeper roots. Similar cases of OttomanizationTurkification of Armenian toponyms were present in the $16^{\text {th }}$ century Ottoman Geographical Registers. ${ }^{36}$ It is ironic to note that in the ongoing process of turning the so called Kurdish toponyms into Turkish ones some toponyms have been restored to their imaginary old Turkish versions, which are actually ancient and medieval Armenian place names. Thus Pertag (Berd $+a k)$ has been renamed Pertek, allegedly its old Turkish name, Esper (Sper)>Ispir, Erdekhan>Ardahan, Shakh>Shatakh, Kers $>$ Kars, Zedkan $>$ Elishkirt, which is the phonetically deformed variant of Alashkert<Vagharsh+a+kert, Geghi>Keghi, in both of which we have the word Gyugh-Gegh meaning village, Guimguim>Vardo, etc. ${ }^{37}$

Gul's statement in Bitlis about Norshin ${ }^{38}$ had controversial repercussions among the country's various political parties. Devlet Bahçeli, the leader of the opposition National Movement Party in particular, criticized Gul for it. Prime Minister Erdogan responded reminding Bahçeli that Manazkert, for example, was an Armenian toponym. "Are you more patriotic than Alparslan? Mustafa Kemal didn't change the name Ankara when he made it the capital of the country. The name Ankara is of Latin origin. Are you saying you are more patriotic than Mustafa Kemal?" asked Erdogan. ${ }^{39}$ We believe this admission by Turkey's Prime Minister should be attributed to the Turkish authorities' desire to evade an awkward situation and show the world that they are democratic and open-minded. Besides, the statement might have been made to deter the Kurdish territorial claims.

Modern Turkish historiography has greatly contributed and supported this systematic program of changing, distorting and appropriating "non-Muslim" toponyms in Turkey. Upon the publication of the works of chroniclers and archival materials of the earlier period of the Ottoman Era, Turkish historians have made use of their rich stock of falsifications and have distorted Armenian toponyms en masse..$^{40}$

Armenia or Ermenistan have been coarsely and retroactively replaced by Eastern Anatolia. The following highlights one such example. In his "Jihan Numa" Kyatib Celebi, a famous Ottoman chronicler of the $17^{\text {th }}$ century, had a special chapter, titled 
"About the Country Called Armenia". When, however, this book was republished in 1957 its modern Turkish editor H. Selen changed this title into "Eastern Anatolia". ${ }^{41}$ The fact, however, is that Armenia together with its boundaries was unequivocally mentioned in the works of Ottoman historians and chroniclers. An excerpt from the said chapter of Kyatib Celebi's Jihan Numa illustrates clearly the falsifications of modern Turkish historians:

Hamdullah says. The Armenia vilayet consists of two parts - Greater and Lesser.... Greater Armenia extends well into Iran and is known by the name of Touman Akhlat. It borders the Lesser Armenia, Rum, Diarbekir, Kurdistan, Azarbaijan ${ }^{42}$ and Aran. Its length covers the area from Erzenel-Rum (Erzurum) to Salmas, while its width - from Aran to the end of Akhlat vilayet. Its capital is Akhlat. In my opinion Greater Armenia at present consists of the Van and Erzurum vilayets, while Lesser Armeniaof Adana and Marash eyalets. In the Takvim-el-Bouldan, ${ }^{43}$ the following cities are mentioned in Armenia: Elbistan, ${ }^{44}$ Adana, Arjesh, Azarbaijan, Bitlis, Barda, Bilekan, Tiflis, Akhlat, Debil, Sultaniye, Sis, Tarsus, Malatia, Van, Vostan, Moush, Erzen-el-Rum and Malazkert. ${ }^{45}$

While Celebi mentioned only part of the territory of Armenia, ${ }^{46}$ the fact that the Ottoman historian admitted the existence of Armenia as a country speaks for itself.

Armenia is referred to by other Ottoman authors of the $17^{\text {th }}$ century as well. The official court historian Evliya Celebi mentions it as Armenistan. ${ }^{47}$ Munejjim Basi, ${ }^{48}$ another Turkish historian of the same century, also wrote about the vast country of Armenia, including into it the cities of Kherd Bert (i.e. Kharberd - L.S.), Erzinkan, Moush, Egin (Akn), Melazjerd (i.e. Manazkert), Bitlis, Akhlat, Arjesh, Vostan, Shirvan and the capital Debil (i.e. Dvin). ${ }^{49}$ From the descriptions of these historians, it becomes evident that in the $17^{\text {th }}$ century official Ottoman historiography recognized the existence of the occupied Greater Armenia, and acknowledged it by its internationnally accepted name of Armenia (Ermenistan), while Cilicia with its Adana and Marash eyalets was recognized by them as Lesser Armenia. Thus, in the $17^{\text {th }}$ century when the Armenian Question was not as yet included into the agenda of international diplomacy, the terms Anatolia or Eastern Anatolia were never used to indicate Armenia. Furthermore, the "Islamic World Map" of the $16^{\text {th }}$ century ${ }^{50}$ and other Ottoman maps of the $18^{\text {th }}$ and $19^{\text {th }}$ centuries have clearly indicated Armenia (Ermenistan) on a specific territory as well as its cities. ${ }^{51}$

Armenia (ناتسنمرا) and Anatolia (sلوطانا) are clearly differentiated in the map published in Istanbul in 1803-1804 (see Map 1). ${ }^{52}$ The Ottoman authors were using the term Armenia till the end of the $19^{\text {th }}$ century. One example is Osman Nuri, the historian of the second half of the $19^{\text {th }}$ century, who mentions Armenia repeatedly in his three-volume "Abdul Hamid and the Period of His Reign." ${ }_{33}$

It is more than obvious that the Ottoman historians and chroniclers in contrast to 
the modern Turkish ones, knew very well Armenia's location and did not "confuse" it with Anatolia (see Map 2).

The word Anatolia means sunrise or east in Greek. This name was given to the Asia Minor peninsula approximately in the $5^{\text {th }}$ or $4^{\text {th }}$ centuries B.C. During the Ottoman era the term Anadolou included the north-western vilayet of Asia Minor with Kyotahia as its center. ${ }^{54}$ The numerous European, Ottoman, Armenian, Russian, Persian, Arabic, Georgian and other primary sources did not confuse the term Armenia with Anatolia. This testifies, inter alia, to the fact that even after the loss of its statehood the Armenian nation still constituted a majority in its homeland, which was recognized by Ottoman occupiers as well.

Therefore, it is very sad to witness today certain Armenian historians of the Diaspora and even diplomats and analysts in Armenia, who have started to substitute the term Western Armenia with that of the ersatz Eastern Anatolia. These people have willingly and submissively undertaken the task of enacting Abdul Hamid's decree of 1880. Incredibly, some Diasporan historians are even using the term Anatolia to indicate the entire Armenian Highland. ${ }^{55}$

Even if this ersatz term of Eastern Anatolia has somehow been put into circulation in Western scientific circles under the influence of systematic Turkish lobbying and falsifications and at times also due to the lack of knowledge, it is unacceptable for us, because the substitution of Western Armenia with the term Eastern Anatolia would mean voluntary renunciation of our homeland, rejection of our centuries-old historical and cultural heritage, denial of the Armenian Genocide, burial into oblivion of its consequences and, last but not least, rendering support to the Turkish negationist position towards the rights of the Armenian nation to Western Armenia. ${ }^{56}$

\section{Conclusion}

The Turkish authorities realize that Armenian toponyms are the product of a civilization spanning several millenia civilization and vivid witnesses of the indigenous presence of Armenians in Western Armenia. The extermination of the native population, however, did not stop with the Armenian Genocide; it was followed by the destruction of Armenian historical and cultural heritage, including the Armenian toponyms.

The policy of Turkification of toponyms in the Ottoman Empire and the Republic of Turkey has gone through several stages:

1. Up to the end of the $19^{\text {th }}$ century, Turkish officials and historians - although they were were appropriating and changing the place names of occupied territories - they still continued to use the names Armenia or Ermenistan.

2. After the Russo-Turkish War of 1877-1878, when the Armenian Question became an international issue, the Turkification of Armenian as well as other Christian toponyms has been carried out more consistently.

3. This process intensified during the Young Turks and the Kemalist regimes, when a full-scale Turkification policy of toponyms targeted all non-Turkic nations. 
4. Finally, during the present fourth stage, decades after eliminating Western Armenia of its native Armenian population, the Turkish authorities, fearing the potential threat posed by the Kurdish factor, have started to reshape their policy by partially restoring the original Armenian names of certain settlements in order to counter their Kurdish variants. However, they try to ascribe Turkish roots to these Armenian toponyms.

All this demonstrates that falsification of toponyms has been and still remains an important constituent part of Turkish demographic policies.

Toponyms are not only linguistic facts, but also accurate and objective historical evidence. The ancient Armenian place names are explicit and emphatic linguistic evidence, which reveal the entire truth about the true native owners of the Armenian Highland. This is why the protection, maintenance and restoration of Armenian toponyms have invaluable strategic significance today.

Notes:

1. Kadir Konuksever, “Kürt açllımı ve Kürt isimleri”, BBC Türkçe, 12 Ağustos, 2009 (www.bbc.co.uk/turkce/haberler/2009/08/090812_kurdish_names.shtml).

2. Muradoğlu A., Ahi Mesut ve Norşin.., Yeni şafak, 11.08.2009. Enver Alper Güvelin, Norşin: Psikolojik eşiğin aşılması, Yeni şafak, 16.08.2009.

3. For more details refer to L. Sahakyan's The Toponyms and Demography of Bardzr Hayk Provinces of Baberd, Sper and Derjan in the 16th century Ottoman Register Books [Bardzr Hayki Baberd, Sper, Derjan gavarneri teghanunnern u zhoghovrdagrutyune XVI dari osmanyan ashkharhagir matyanne $\neg$ rum] published by "Lousakn" Publishers, Yerevan, 2007, pp. 235-237, 250, 251, 259, 261.

4. Sahakyan L., Toponyms and Demography, op. cit., pp. 83-84.

5. Celebi, Evliya: Foreign Sources about Armenia and Armenians, Vol. 4, Turkish Sources, Vol. 3, [Otar akhbyurnere Hayastani yev hayeri masin, h. 4, Turkakan aghbyurner, Evliya Celebi] translated into Armenian from the original with a foreword and commentaries by A.Kh. Safrastyan, published by the Arm SSR. Academy of Sciences, 1967, p.127.

6. Movses Khorenatzi, The History of Armenia [Hayots patmutyun], Yerevan, 1999, p. 104.

7. For a detailed etimological analysis of Baberd, see L. Sahakyan's above mentioned monograph, pp.130-131.

8. Celebi, Evliya: Foreign Sources... [Otar aghbyurnere...], Vol. 4, p. 127.

9. Ajaryan, H.: Armenian Etymological Dictionary [Hayeren armatakan bararan], Vol. 2, Yerevan, 1973, p. 469. See also New Wordbook of the Haykazyan Language [Nor bargirk haykazean lezvi], Vol. 1, Yerevan, 1981, State University Publ. House, p.1026.

10. Celebi, Evliya: Foreign Sources... [Otar akhbyurnere], Vol. 3, p. 120.

11. Ibid, p. 155 . 
12. Ajaryan, H. Armenian Etymological Dictionary [Hayeren armatakan bara $\neg$ ran], Vol. 1, Yerevan, 1971, State University Publ. Housep. 106-108.

13. Celebi, Evliya: Foreign Sources ...[Otar akhbyurnere ...], Vol. 4, p. 157.

14. Modern History of Armenia in the Works of Foreign Authors [Novaya istoriya Armenii v trudax sovremennix zarubezhnix avtorov], edited by R. Sahakyan, Yerevan, 1993, p. 15 (in Russian).

15. Tserents, National Survey: The Ottoman Monarchy, Turkish Armenians and Russian Armenians [Azgayin tesutyun, Osmanyan Inknakalutyun, tachkahayk yev rusahayk], Pordz, Tpkhis, 1897, N VII-VIII, pp. 204-205. Modern History of Armenia in the Works of Foreign Authors, p.17 (in Russian).

16. Frat N., Vulpes Vulpes Kurdistanica, Günlük, 17.8.2009, (www.gunluk gazetesi.com).

17. Frat N., Ibid.

18. Ayşe Hür, Tez zamanda yer isimleri değiştirile, Taraf, 01.03.2009.

19. Modern Turkish historian Aishe Hyur, writes that the measures taken to systematically change non-Turkish names were sped up during World War I (Bin Yerin İsmi Değişti, Hangi İsim Hangi Dile ait? www. kenthaber. com/Haber/Genel/ Dosya/gundem/28-bin- yerin-ismi-değişti).

20. Başbakanlık Osmanlı Arşivi, Dâhiliye Nezâreti, İUM, nr. 48/17, lef: 2. M. Şükrü Hanioğlu, Enver Paşa, DIA, XI, İstanbul, 1995, ss. 261-264. A. Yüksel, Doğu Karadeniz Araştırmaları, İstanbul, 2005, ss. 21-22.

21. Tirebolulu H. [Huseyin Avni] Alparslan, Trabzon İli Lâz mı? Türk mü?, Giresun, 1339. s. 17.

22. Aramaic Toponyms in Turkey - A Demand of the Aramaean Diaspora, Open Letter to Mr. Beşir Atalay, Interior Minister of Turkey, made public by J. Messo, President of the Syriac Universal Alliance, Stockholm, 18 May, 2009,

http://www.americanchronicle.com/articles/view/103515; The Turkification of Cyprus and the Orging of History, www.kypros.org/CyprusPanel/cyprus/Cproblem.html.

23. Hoşoğlu K., Köylerin Eski İsimleri, Eski İsimler Hakkında bilgiler, Rize Halk Eğitim Yayınları, 2001.

24. Sahakyan L., Toponyms and Demography, op. cit., pp. 136-272.

25. Aktar A, "Yer isimlerini Turkleştirmek...", Taraf, 23 Ekim, 2009.

26. Türker Ş., 28 bin yerin ismi değişti, Hangi ismin hangi dile ait olduğu bilinmiyor!, Vatan, 16.08.2009, www.esoyle.com/2009/08/30/28-bin-yerin-is $\neg$ mi-değişti.

27. Türker Ş., op. cit.

28. The original toponyms are given in parentheses.

29. Türker Ş., op. cit.

30. Soviet Armenian Encyclopedia, Vol. 1, [Haykakan sovetakan hanragitaran], Yerevan, 1974, p. 373. Also A Concise Armenian Encyclopedia, Vol. 1, [Haykakan hamarot hanragitaran], Yerevan, 1990, pp. 192-193.

31. Bilir O., Tunceli, Dersim Olsun Tekilfini Ekimde yeniden, Bir Gün, 2009, 19 Agustos. Refer also to www.birgun.net

32. Bilir O., Ibid 
33. Tunçel H., Türkiye'de İsmi Değiştirilen Köyler, Sosyal Bilimler Dergisi, Firat Universitesi, 2000, cilt 10, say1 2.

34. Türker S., 28 bin yerin ismi değiști..., Vatan, 16 Agustos, 2009.

35. See Yuksel A., Doğu Karadeniz Arastırmaları, İstanbul, 2005, s. 21-22.

36. For the details, see Lusine Sahakyan, Toponyms and Demography of Bardzer Hayk Provinces of Baberd, Sper and Derjan in the 16th century Ottoman Register Books [Bardzr Hayki Baberd. Sper, Derjan gavarneri tekhanunnern u zhokhovrdagrutyune XVI dari osmanyan ashkharhagir matyannerum], pp. 77-108.

37. Bilir O., Tunceli, Dersim Olsun Tekilfini Ekimde yeniden, Bir Gün, 19 Agustos 2009. Refer also to www.birgun.net.

38. Muradoğlu A., A. Mesut ve Norşin.., Yeni Şafak, 11.Ağustos, 2009. Enver Alper Güvelin, Norşin: Psikolojik eșiğin aşılması, Yeni Şafak, 16.08.2009.

39. Erdoğan Bahçeli'ye yeni sert sözlerle yüklendi, Hürriyet, 10 Kasım, 2009.

40. See Sahakyan L., Toponyms and Demography, op. cit., pp. 71-108, 130-135.

41. For details refer to A. Papazyan's Turkish Documents about Armenia and Armenians (XVI-XIX cc) [Turkakan vaveragrere Hayastani yev hayeri masin (1619-rd darer)], Yerevan, 1999, p. 125.

42. Azerbaijan - Atrpatakan, a province of Iran.

43. Takvim-al-Buldan" is the Statistical Data-book of Abul Fida, an Arab historiographer and geographer. It served as a source book for Kyatib Celebi (Turkish Sources about Armenia, Armenians and Other Trans-Caucasian Peoples [Turkakan aghbyurnere Hayastani, hayeri yev Andrkovkasi myus zhoghovurdneri masin,, vol. 2, Yerevan, 1964, p. 258).

44. Elbistan-Albistan, a town in Cilicia in the Zeytun caza of the Marash province.

45. Turkish Sources...[Turkakan aghbyurnere...], Vol. 2; Kyatib Celebi, Jihan Nyuma, pp. 29-30.

46. Refer also to A. Papazyan's Turkish Documents about Armenia and Armenians (XVI-XIX cc) [Turkakan vaveragreri Hayastani yev hayeri masin (16-19-rd dare], pp.112-114, 121-122.

47. Evliya Celebi, Kniga puteshestviya. Predislovie A. P. Grigoreva. Primechania i komentarii A. Grigoreva, A. D. Jeltyakova. Vypusk 2., Izd. Nauka, Moskva, 1979, p. 102 (in Russian).

48. Refer to Munejjim Basi: [Turkish Sources...], vol. 2, p.183.

49. Ibid., pp. 199-200. In Arabic and Turkish sources the toponym Dvin has been distorted and written in various ways like Debil (refer to Vol. 2 of Dictionary of Toponyms of Armenia and the Adjacent Regions, Yerevan, 1988, p. 68) Douin, Dabil, Adabin and Douviy (refer to S. Vardanyan's The Capitals of Armenia [Hayastani mayrakaghaknere], Yerevan, 1995, p. 109.)

50. The Islamic World Map was drawn in the 1570s. Its diameter is $28.5 \mathrm{~cm}$, and it is kept in the Bodleian Library, Oxford, manusc. Var.317 f9v-10r (Refer to R. Galchian's Armenia in World Cartography, Yerevan, 2005, p.148.

51. The Second Map of the Mediterranean Region (reprinted in R. Galchian, ibid., p. 228). 
52. Asian Turkey was printed in 1803/1804. Size: $72 x 54 \mathrm{~cm}$, British Library, LondonOIOC 14999, vol. 2 (2), f.18. The second map in The Mediterranean Region, size: $80 x 58$ cm, British Library, London-OIOC 14999, V. 2 (2), f. 5.,"The Ottoman Country", published in 1867, size: 42x29 cm, The British Library, London-Maps 42.d.1, f.2 (Refer to R. Galchian's monograph, ibid. pp. 226, 246).

53. The Turkish Sources [Turkakan aghbyurner]. Vol. 4. Transl. from the original by A. Kh. Safrastyan and G. H. Santurjyan. Yerevan, 1972, pp. 126, 131, 133, 136, 165, 167, 172, 175, 180, 184, 188, 190.

54. Soviet Armenian Encyclopedia [Haykakan sovetakan hanragitaran], vol.1, Yerevan, 1974, p. 373. For details about Turkish attempts to change the place name of "Western Armenia" with that of "Eastern Anatolia" see Zograbyan L.N., [Orfografia Armyanskogo Nagoriya], Yerevan, 1979, p. 14-15. See also E. Danielyan's article titled Issues of Ancient Armenian History in Historiology [Hin Hayastane patmutyan hayetsakargayin himnahartsere patmagrutyan mej], published in Patmabanasirakan Handes (Historico-Philological Magazine), 2003, N3, pp. 30-37, as well as his article titled Armenia and Armenian Geographical Names: A Scientific Assignment to Protect the Armenian Natural and Historical Environment [Hayastann u haykakan teghanunnere, hayots bnapatmakan mijavayri pashtpanutyan gitakan arajadrank], published in VEM, Yerevan, 2009, N1, pp. 13-15.

55. Ronald Grigor Suny, Looking Toward Ararat: Armenia in Modern History, Bloomington, Indiana University Press, 1993. The Armenian People from Ancient to Modern Times, Vol. 1, New York, St. Martin's Press, 1997, pp. 22, 26, 37. Ayvazyan A.: The History of Armenia as Presented in American Historiography, a critical survey, Yerevan, 1998, pp. 37-40.

56. Refer to Armen Ayvazyan's Western Armenia vs. Eastern Anatolia, Europe and Orient (Journal of the Institute Tchobanian, Paris), No. 4, 2007.

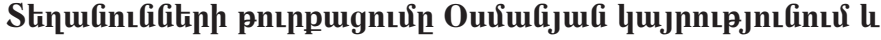

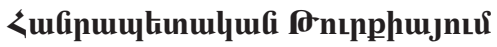

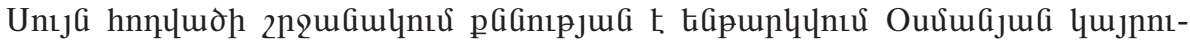

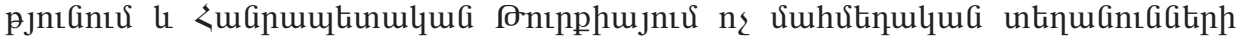

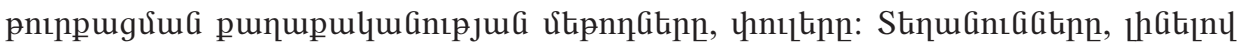

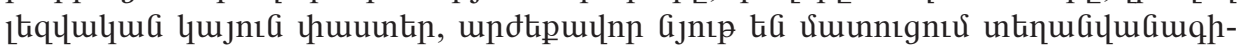

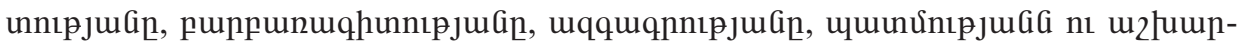

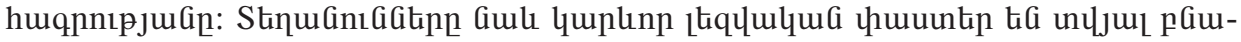

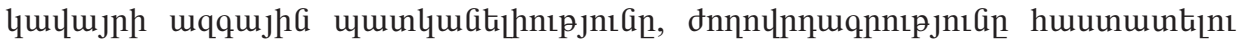

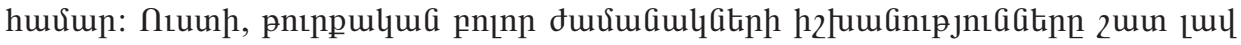

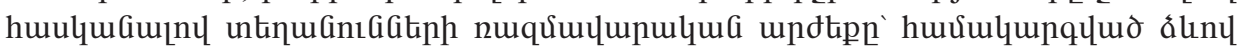

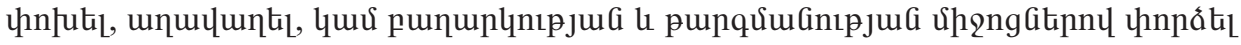

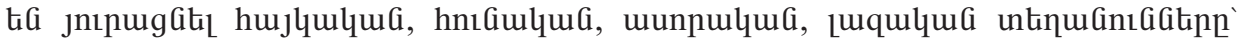

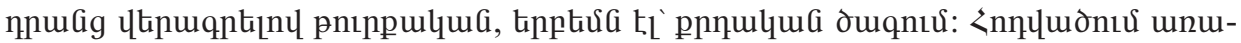




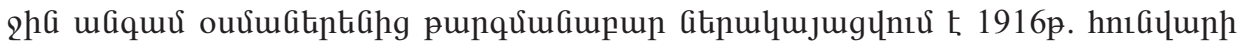

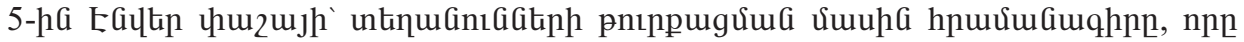

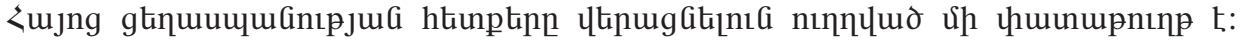

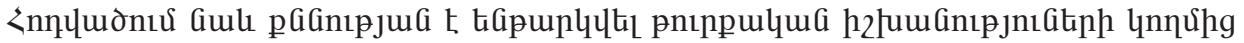

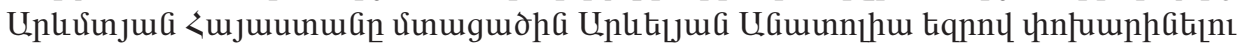

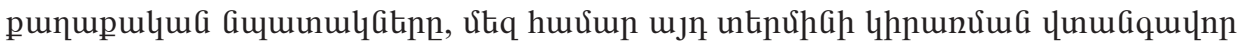

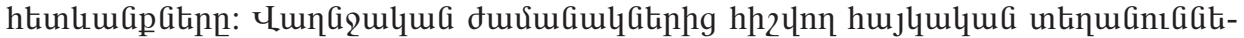

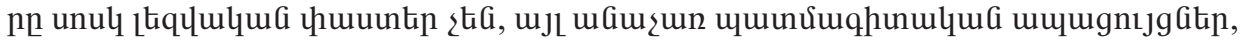

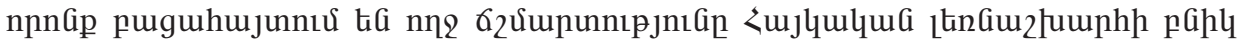

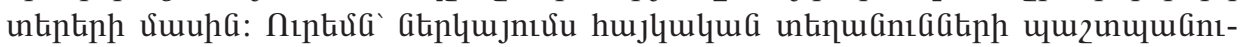

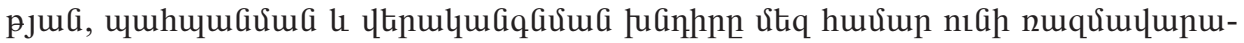
qua uGqGuhumbih GizuGulynıpjnı: 